\title{
14
}

\section{Afterword: Land Transformations and Exclusion across Regions}

\author{
Philip Hirsch
}

\section{Introduction}

The preceding chapters of this book give a central place to the Powers of Exclusion framework for understanding transformations in land relations, as developed in our 2011 book on Southeast Asia (Hall et al. 2011). A couple of the main aspects of the two books make for an interesting comparison. The first is that each employs a regional frame of reference to explore themes in changing land relations. The second is their respective development and application of a common conceptual framework. These commonalities beg the twin questions I seek to address in this chapter:

- Are there particular regional characteristics and dynamics that mark land relations with reference to exclusionary processes?

- Is the conceptual approach developed in one region applicable or adaptable to another?

These questions are explored first by considering what a regional approach to land relations might mean. The main part of this Afterword then makes a number of comparative observations between Melanesia and Southeast Asia, drawing out implications for the ways in which powers of exclusion help frame our understanding of commonalities and differences between 
regional patterns of changing land relations. The essay concludes with a recap of tensions between common forces reshaping land relations across both regions, on the one hand, and regional specificity on the other.

\section{A Regional Approach to Land Relations}

During our several writing retreats as we co-authored Powers of Exclusion, Derek Hall, Tania Murray Li and I wondered out loud on a number of occasions whether there would be uptake of our approach at a wider geographical and interdisciplinary level, with reference to country cases beyond our regional area of interest in Southeast Asia, or-and most ambitiously-with specific reference to other world regions. Reviews, informal discussion, and feedback from colleagues working in the field of agrarian studies and land-oriented activism in Africa, Latin America and South Asia have been positive in this regard, and they have encouraged us with the sense that the Powers of Exclusion framework does indeed have wider geographical resonance. However, not until the present volume has there been a sustained monograph-length effort to test the framework with reference to another world region.

What does a regional approach to understanding changing land relations entail? Unlike 'fugitive' resources that move across jurisdictions, such as water in transboundary river basins, or riverine and ocean migratory fisheries, and unlike environmental pollution such as smoke haze or greenhouse gas emissions, land is fixed in space and hence is not often treated as a transboundary resource. Land is also jealously protected as a national asset that is subject to national policy prerogative and ownership, or to more locally specific arrangements associated with ethnic identity. Yet despite this fixity of land in particular locales and national spaces, land is also subject to regional analysis in at least three main respects.

First, regions are often defined by particular characteristics that have relevance to land relations. Cultural norms such as patron-clientage, reciprocity, structures of political authority, and religious affiliation have regional associations, albeit in ways usually much more complex than simple stereotyping allows for. Also, regional location has both historically and in a more contemporary sense subjected land relations to external economic influences in particular ways. Different world regions have been subjected to quite specific colonial and post-colonial influences, and to Cold War and post-Cold War changes. Agro-ecological patterns 
of farming characterise regions, with implications for land use, land tenure, and rural social relations. Similarly, population dynamics within and between regions are location-specific, with implications for pressures on land.

Second, regional political-economic dynamics are integral to the defining of regions beyond more archaic and static cultural bases for regional demarcation. The discursive construction of regions is closely linked to these dynamics, so that, for example, Southeast Asia and subregions within it have been associated with institutionalised regional arrangements such as the Association of Southeast Asian Nations and the Greater Mekong Subregion. Regions are also naturalised around river basins, shared maritime zones, island groups, and so on. The governance of natural resources within, and with reference to, these regional constructions is in part shaped by institutionalised arrangements, aid programs, and other interventions that adopt a regional approach. In Southeast Asia, for example, the Greater Mekong Subregion's neoliberal agenda of facilitating private sector-led infrastructure development and transboundary flows of goods and investment capital brings with it a suite of policy and legal reforms geared to strengthening private property rights in land, enhancing wealth creation through markets (not only in mobile goods and services but also through mortgageable land), and through other measures. In the Pacific, regional arrangements and external interventions through aid flows appear to be much more circumspect in the ways in which they intervene in customary property arrangements.

Third, intra-regional flows and regional interaction with the global economy bind regions, internally and externally, in ways that have significant implications for land relations. In particular, concern during the past decade over land grabbing plays into regional dynamics. But these dynamics are often quite specific to one region or another. In Southeast Asia, transboundary land deals dominate the investment in boom crops such as rubber and sugar. In mainland Southeast Asia, or the Greater Mekong Subregion, investments by Chinese, Thai and Vietnamese companies in Cambodia, Laos and Myanmar respectively forge a particular regional dynamic, which is matched to a lesser degree by Malaysian and Singaporean investments in oil palm in Indonesia. In Melanesia, in contrast, this intra-regional dynamic is lacking, and indeed, much of the investment through land deals is from the region's northern neighbours. 


\section{Some Comparative Reflections Between Melanesia and Southeast Asia}

Regional patterns of changing land relations in Melanesia and Southeast Asia reflect each region's historical experience of colonisation and state formation, as well as innate cultural and agro-ecological specificities. We can explore commonalities and contrasts with reference to the four key powers of exclusion that we set out (in Hall et al. 2011): markets, regulation, force and legitimation. First, however, it is useful to consider the respective regional contexts in which the powers operate.

\section{The Politico-Historical Regional Backcloth}

Agrarian structures are the basis on which property relations in land develop. Southeast Asian and Melanesian societies have quite different backgrounds in their pre-colonial and colonial-era structuring of land and labour vis-à-vis capital and central authority.

Historically, paddy rice has been the staple crop in lowland parts of both mainland, and insular and peninsular, Southeast Asia; and even in upland areas dominated by swiddening, rice has provided a main staple. Rice is commonly associated with smallholder peasant farming (Bray 1986), and historically irrigation systems have associated such cultivation with wider patterns of kingship, quasi-feudal land relations, and patronage. Of course, smallholder farming varies across the region, and histories of colonialism, revolution, land reforms, and other processes are quite diverse and country-specific. Nevertheless, land issues were prominent in most of Southeast Asia's anti-colonial grievances, in post-Independence conflicts, in the left-right struggles of the Cold War, and in the post-revolutionary regimes and subsequent reforms of Indochina.

In Melanesia, on the other hand, swidden cultivation systems and the absence of pre-colonial or colonial state involvement in small-scale agriculture, which has been mainly swidden-based, provides a very different backcloth for land relations. This is related to the absence of large-scale kingship, and the tribal, clan and lineage basis for authority, including assignation of individual and communal rights over land. Similarly, the decolonisation process in Melanesia reinforced the quite different agrarian structure and the role of the post-Independence states, which were shaped much less by Cold War dynamics than in Southeast Asia. 
Additional to the different colonial and post-colonial histories of the two regions, the scale at which society is organised around land influences the nature of exclusion in the two regions in question. The intimate exclusions discussed in Powers of Exclusion are considered in terms of familial and neighbourly relations at the village level. In the smaller scale societies of the Pacific, personal ties also operate within the government system to a greater degree and in a seemingly more obvious sense, and with greater impunity, than in larger bureaucracies. The quasi-feudal arrangements around land and labour in Southeast Asia that have shaped revolutionary and reform programs alike are more or less absent in Melanesia, and the tribal rather than peasant-based nature of society has, as a result, tended to show greater persistence than in Southeast Asia.

Land is political everywhere, but in some cases it is more overtly related to big-picture political agendas than in others. The politics of exclusionary processes around land have had quite different meanings in the two regions in question. Rural support for anti-colonial movements in Southeast Asia was closely linked to resentment over impositions on land and labour (Scott 1976, 1985). Land-to-the-tiller campaigns became embroiled in Cold War tensions, both through revolutionary movements and in counter-revolutionary pre-emptive reforms. Some socialist experiments went beyond land redistribution, with programs of cooperativisation and collectivisation, including the extreme example of Khmer Rouge elimination of all individual claims to, and family working of, land.

In Melanesia, the politics of decolonisation were nowhere near as closely tied up in agrarian grievances as they were in Southeast Asia. Land reform has never assumed the redistributive agenda that it has in Southeast Asia (Chapter 1, this volume), whether through the vehicle of successful communist revolutions or as a pre-emptive measure against revolutionary movements. Ironically, because of this absence of socialist land reform, Melanesia has also not been subject to exclusions associated with the postsocialist market-based reforms, which has been one of the strongest forces for renewed concentration of land in Cambodia, Laos, Vietnam andin a different geopolitical and structural context-Myanmar (Hirsch and Scurrah 2015). 


\section{Markets: Boom Crops and Land Grabbing}

The phenomenon of land grabbing has drawn global attention to injustices associated with unequal political-economic power and has revived interest in land questions around the world more generally. Driven in particular by the 2008 food price spike and concerns over underinvestment in agriculture that encouraged or legitimised a spate of 'land deals', land grabbing has increasingly come under scrutiny at a number of levels, one of which is definitional. Land grabbing is not only open to discursive interpretation, but it also manifests itself in regionally specific ways.

In mainland Southeast Asia, the so-called land grab takes a number of forms. Most often discussed is the rush of transboundary investment in agricultural and other land-hungry resource projects by commercial interests from the more industrialised and land-scarce countries of China, Thailand and Vietnam in the perceived land and natural resource-abundant countries of Cambodia, Laos and Myanmar. In reality, domestically driven land grabbing by the military in Myanmar, and by crony tycoons in Cambodia, is equally significant. Large-scale land accumulation has also accelerated in Thailand, historically a country of smallholders (Laovakul 2015). In insular and peninsular Southeast Asia, Malaysian investment in oil palm in particular is associated with dispossession of ethnic minorities and with forest clearing. Despite the global legitimation of land grabs by concern over food shortages, the boom crops behind much of Southeast Asia's land grabbing are mainly industrial, including rubber and crops grown for biofuels. The latter are often what have been termed 'flex crops' (Borras et al. 2014), such as oil palm and cassava, but the driving force for their expansion has mainly come from the biofuel sector. While market demand has driven expansion, the large-scale concessions granted to transnational regional capital have been facilitated by the neoliberal notion of underutilised lands whose suboptimal use can be corrected by market-based measures. This follows longer standing colonial practices that often characterised swidden fallows as 'wastelands' (Ferguson 2014).

In Melanesia, the land onto which oil palm and other boom crops have expanded has nominally remained in customary hands. However, arrangements for alienation of such lands are evident in various forms, including the special agricultural and business leases (SABLs) in Papua New Guinea (PNG), which provide an institutional means for concentration of land in the hands of corporate interests while maintaining nominal customary tenure (Chapter 6, this volume). 


\section{Regulation: Land Formalisation Through Titling}

In Southeast Asia, marketisation of land often goes hand in hand with formalisation through land titling. Whether marketisation creates the demand for titling or vice versa remains an open discussion. In Melanesia, given that only a very small proportion of land is under freehold or state land leases, land exclusions are driven by market pressures through informal transactions, for the most part on customary land (Chapter 5, this volume). This implies that kastom provides a sound basis for relational market transactions that tend to fly in the face of conventional thinking about formalisation and individualisation of property rights as a basis for market transactions in much of Southeast Asia. Yet at the same time, formalisation works within the framework of customary arrangements around land to privilege certain groups with respect to boundary making and to catalyse innovative exclusionary institutional arrangements that exclude even in the absence of fully individualised land title (Chapter 12, this volume).

The authors of the introductory chapter to this volume follow Rose (1994) in suggesting that social relations embedded in property in the Spearhead states of Melanesia are concealed by formalisation through registration under Torrens Title. Most of the land titling in Southeast Asia has similarly been carried out under programs employing the Torrens system of title by registration, that is, without reference to historical lineage of possession. Land titling programs have received significant technical and financial support from the Australian government and the World Bank. Most have been run by the Australian company Land Equity International, an offshoot of the surveying arm of the Australian mining giant BHP Billiton. Thailand's land titling program, established in the mid-1980s, served as a model that was adopted in Laos, the Philippines, and to varying degrees in other Southeast Asian countries. While these programs were the target of critique, and have faced significant challenges in their importing of particular assumptions about property rights systems developed in capitalist economies under mainly liberal democratic governance, there has been relatively little resistance to their adoption. In part, this may be attributable to the post-socialist economic contexts in which market-based institutions are being developed quite aggressively by the respective governments of countries such as Laos, Cambodia, Myanmar and Vietnam. 
In Melanesia, in contrast, the usurping of customary land tenure by individualised property rights has been subject to heated debate (Hughes 2004; Fingleton 2005). The same company that implemented the main Torrens Title-based land titling programs in several Southeast Asian countries, Land Equity International, has more recently led Vanuatu's Land Program, but without succeeding in overcoming the nepotistic or otherwise corrupt practices of ministers gifting land to government officers. Because of the patronage relations in a small-scale society, this leasing of state land is referred to as another level of 'intimate exclusion' (Chapter 9, this volume).

An interesting point of comparison emerges in the formalisation of customary land tenure. On the one hand, the restriction of title to collectively managed land subject to rights of use by association with a particular community, clan, or other group serves as a protection against alienation of individual land title, whether through voluntary decision or as a result of distress sale. In parts of Southeast Asia, customary rights associated with locale or ethnic distinction continue to play a role in negotiating tenure arrangements that push back on the neoliberal model of fully alienable property rights in land. In eastern Indonesia, for example, farmers appear to give priority to security against alienation rather than individually mortgageable and alienable property rights following the neoliberal model (Kristiansen and Sulistiawati 2016). In northeastern Cambodia, the 2001 Land Law has provided the basis for community title in indigenous communities, albeit following a convoluted and expensive bureaucratic process. But, at the same time, formalisation of customary lands also raises the spectre of 'powerful men', comparable with those mentioned in Chapters 1 and 9 in this volume, excluding fellow members of the customary group and even leasing out the land in question in a process echoing Powers of Exclusion's 'intimate exclusions' (Chapter 6, this volume). Milne (2013) presents an interesting such case in northeastern Cambodia, where some farmers have opted for individual over community title out of concern that the latter can be exploited by unscrupulous leaders. These intimate exclusions also take on an important gender dimension in $\mathrm{Ni}$-Vanuatu social relations in the process of formalisation (Chapter 10, this volume). 


\section{Force: Scales of Authoritarianism}

In Powers of Exclusion, our consideration of force as a power of exclusion looks largely at the ways in which violence or threats of violence serve to exclude, beyond the enforceable regulatory power of the state and often by extra-legal means. In Southeast Asia, state authoritarianism has waned and waxed, and it has taken various forms ranging from outright military dictatorship to illiberal communist regimes, including regimes best characterised as 'neoliberal authoritarian' (Springer 2009). Control over land and restrictions on land-based activism or right of redress for land grabbing and related injustices are a significant part of the extraconstitutional exercise of authority, such as that exerted in the enforced disappearance of community development leader Sombath Somphone in Laos in December 2012. ${ }^{1}$ Elsewhere, notably in Cambodia and the Philippines, violence with impunity is carried out or threatened by those with direct vested interests in land, often supported by connections in high places. As land prices have skyrocketed across the region, so the threat of violence has pervaded land disputes.

The association between state power and local violence is not so apparent in this volume. Rather, local and highly gendered structures of authority appear to wield this power of exclusion more autonomously. This is not to suggest that such power is unrelated to wider developments. On the contrary, in Vanuatu we see local powerful men acting as 'masters of modernity' (Chapter 9, this volume), and an interweaving of property and authority in Solomon Islands such that 'land disputes have now become a key arena for the performance of masculine authority and prestige' (Chapter 13, this volume). Furthermore, also in Solomon Islands and perhaps related to the relatively small-scale society within which violent or potentially violent land disputes are played out, conflict is constitutive not only of local social relations but also of wider political authority in a manner that helps shape state formation (Chapter 13, this volume).

Both Melanesia and Southeast Asia exhibit violence in exclusions based on ethno-territorial claims (Hall et al. 2011: 11; Chapter 2, this volume). But in Melanesia, such violence extends into peri-urban and even urban zones, whereas it tends to be concentrated in peripheral frontier lands in Southeast Asia. The centrality of clan, tribe and lineage in social and political organisation in Melanesia means that state and kastom co-exist

1 See the website www.sombath.org/en/. 
within a more singular polity, particularly with reference to land, than in the more centralised and much larger states of Southeast Asia. The fact that the ruling regimes in the latter are all associated with a numerically dominant ethnic majority claiming national patrimony also gives ethnoterritorial land claims a different place and role with respect to the distinction between extra-legal force and state-sanctioned violence.

\section{Legitimation: Custom, Conservation and Developmentalism}

In Melanesia, the status of customary landholder carries a great deal more weight in legitimising smallholders, not only to farm and live on the land in question, but also to derive resource rents or compensation payments when outsiders extract value from the land (Chapter 1, this volume). However, the role of kastom is complex. At one level, it is often understood as an inclusive basis for counter-movements to keep exclusionary market forces at bay. At another level, however, kastom can be a legitimating power of 'intimate' exclusion in its own right, particularly as it interacts with rights of chiefly authority (Chapter 11 , this volume).

In both Melanesia and Southeast Asia, conservation has been a legitimating pretext for exclusion. In particular, forest carbon schemes (Hall et al. 2011: 84; Chapter 8, this volume) have facilitated the identification of areas to be excised from agricultural use in the name of forest protection. It is noteworthy that market principles underlie such schemes, illustrating the overlaps in powers of exclusion in both cases.

In both regions also, large-scale land acquisition has been legitimated by the investment that large plantation schemes attract for relatively high value 'boom crops', which we described as cases of 'volatile exclusion'. In PNG, oil palm dominates this kind of investment (Chapter 7, this volume), and SABLs are the key vehicle for investors to gain access to customary land. They do so through a process facilitated but not brokered by state authorities. This valorisation of land potential in pursuit of productivity and profits is a response to market forces, but more immediately it is legitimised by the promises of modernity contained in the land use itself and the associated infrastructure that it attracts. These developments are typically carried out as 'agro-forestry' projects, although it should be noted that this term denotes a peculiar set of practices in Melanesialogging followed by plantation or agricultural development-whereas in Southeast Asia, it refers to integrated land uses mixing annual and 
perennial crops, or sometimes-as in the colonial-era taungya system in Burma-a progressive succession of swidden systems into silvicultural systems as shifting cultivation is phased out in favour of long-term teak rotations.

There are commonalities between upland Southeast Asia and Melanesia in the legitimation of possession in shifting cultivation systems through the act of cultivating the land. In both regions, such possession is traditionally a temporary right of exclusion (Chapter 1 , this volume), albeit one whose form and relative impermanence varies greatly from one agro-ecological and ethnic context to another. Similarly, in both regions, there are many cases where exclusive tree ownership may not coincide with the recognition of landownership of the plot on which the trees are growing (Peluso 1995).

A key contrast in the legitimation of exclusion through colonial or postcolonial state-assigned property rights occurs in the realm of customary tenure. Whereas land alienated by titling in most Southeast Asian countries is more or less off-limits for customary claims, Torrens Title continues to be contested in all of the Spearhead states discussed in the current volume, and Vanuatu even went to the extent of abolishing freehold land after Independence (Chapter 1, this volume). Powers of Exclusion tends to focus on state lands, notably the untitled 'political forest', as sites of contestation in Southeast Asia that are subject to legitimacy-based claims, with more emphasis on market-based exclusions in the case of titled lands. The situation in Melanesia appears to be considerably more open, fluid and contestable, presumably because of the continuing debate on the suitability, necessity, or otherwise of alienable property rights in the development context of Melanesian societies (Fingleton 2005).

These tensions over property rights find their way into public discourse and debates in different ways in each region. In both Melanesia and Southeast Asia, the neoliberal argument that legitimates exclusion through individualised, alienable land title has considerable traction (Chapter 1, this volume), but more so in the latter than in the former. The argument tends to be rolled out in Melanesia by certain neoliberal economists as an explanation for continuing underdevelopment (Hughes 2004), a notion hotly contested by others (Fingleton 2005), whereas in Southeast Asia the post-facto neoliberal economic discussion on land titling has long sought to measure its effect on productivity (Feder 1987)—a discourse that is less challenged, but that raises conundrums on the extent to which 
public cultivated land in particular should be fully titled (Hirsch 2011). In Melanesia, the experience of land tenure reform that violates the moral basis of customary land principles through excessive individualisation has been one of failure. This does not necessarily exclude outsiders from access rights to land, but it requires that such rights are contingent on establishing place-based social relationships and enduring goodwill between in-migrants and existing customary landowners (Chapter 5, this volume). Nonetheless, neoliberal ideology holds increasing sway, even in the absence of a Torrens Title system, legitimating exclusionary arrangements such as SABLs (Chapter 7, this volume) and 'special economic zones' (Chapter 12, this volume).

In one respect, the requirement to formalise at the level of customary land, rather than by individualisation of titles, has provided a partial protection against land alienation in Melanesia. However, it has by no means pre-empted land grabbing. The lease-leaseback system in PNG allows wholesale alienation and abuse of authority by those in positions of power at the community level, who are thereby empowered to do documented land deals with external investors (Chapter 6, this volume). While the form of such exclusions may be different from state-brokered deals in Laos and Cambodia, for example, the effect is not altogether different. Nevertheless, land tenure reform in favour of customary group title registration in Melanesia might afford greater protection against such land grabbing.

The Melanesian ideology of landownership described in this volume (Chapter 1, this volume), based in membership of tribes or clans or lineages, is quite different from much of what we encounter and describe for Southeast Asia in Powers of Exclusion. The formalisation of these links as a key process of state formation is similarly difficult to recognise in the historical experience of Southeast Asia. The role of land titles in identification with the state as a form of urban and even national citizenship appears particularly strong in the urban context of Port Moresby (Chapter 4, this volume) - a phenomenon that remains underexplored in Southeast Asia, although a recent study in Bangkok suggests important links between land security and a sense of urban belonging in 'informal'—albeit long-established—settlements (Herzfeld 2016). 


\section{Conclusion}

What do the foregoing comparative comments reveal about regional processes and conceptual applicability of the Powers of Exclusion framework across regions? We see a number of common external forces pertinent to land relations in both regions: both have been shaped by colonial and post-colonial histories that incorporate land as a site of contestation at the state-society nexus. Both regions have gone through processes of marketisation and formalisation of bounded property arrangements. Both are subject to transnational investment and policy reform inspired by neoliberal development agendas. Both have seen the emergence and problematising of land grabbing. Corruption and violence enters the field of land relations in both regions, and in both there have been challenges to full commodification of land.

Yet we have also seen regionally specific dynamics. History and culture are of paramount importance, but there is also a need for caution in explaining regional dynamics in overly simplified historico-cultural terms, particularly in a region such as Southeast Asia, which is often considered to be an imagined or constructed entity rather than having an innate geographical logic (Acharya 2013). The political economy of land grabs differs fundamentally between the two regions. In part this may be an issue of scale. In the introduction to this volume, the authors raise the question of whether the quantum difference in population size of the countries in Melanesia and Southeast Asia makes a difference to the conceptual framework's application across regions. For example, we have seen that the more 'intimate' nature of the political systems in Melanesia raises questions of exclusions based on personalised aspects of the political process. But beyond scale, the nature of state authority, the very different experiences of the Cold War and subsequent reforms, and the difference in the drivers and shape of land reform initiatives, also set the regions apart.

A final key difference between land struggles in Southeast Asia and Melanesia is the significance of urban land conflicts in the latter (Chapters 2-4, this volume). This is not to suggest that urban land issues are insignificant in Southeast Asia, but there are three reasons for the relative absence of urban considerations in Powers of Exclusion. The first is simply that we wrote the book as part of a project concerned with the agrarian transition in Southeast Asia, and scoped it mainly as a rural-based 
analysis. The second is that much of the literature and public discussion on land issues in Southeast Asia is based on rural land conflicts, which have a history of political salience in the region. And the third is that most—although far from all—urban land in Southeast Asia is registered with private land title, and exclusions are therefore largely market-based, so that conflict tends to be less overt in urban than in rural areas. This is in direct contrast to the situation in Melanesia. With this in mind, there is still much to learn from this volume in re-addressing urban land questions in Southeast Asia through the lens of exclusion.

\section{References}

Acharya, A., 2013. The Making of Southeast Asia: International Relations of a Region. Ithaca (NY): Cornell University Press.

Borras, S.M. Jr, J.C. Franco, R. Isakson, L. Levidow and P. Vervest, 2014. 'Towards Understanding the Politics of Flex Crops and Commodities: Implications for Research and Policy Advocacy.' The Hague: Transnational Institute Agrarian Justice Program.

Bray, F., 1986. The Rice Economies: Technology and Development in Asian Societies. Oxford: Blackwell.

Feder, G., 1987. 'Land Ownership Security and Farm Productivity: Evidence from Thailand.' Journal of Development Studies 24: 16-30. doi.org/10.1080/00220388708422052.

Ferguson, J.M., 2014. 'The Scramble for the Waste Lands: Tracking Colonial Legacies, Counterinsurgency and International Investment through the Lens of Land Laws in Burma/Myanmar.' Singapore Journal of Tropical Geography 35: 295-311. doi.org/10.1111/sjtg.12078.

Fingleton, J. (ed.), 2005. Privatising Land in the Pacific: A Defence of Customary Tenures. Canberra: The Australia Institute (Discussion Paper Number 80).

Hall, D., P. Hirsch and T.M. Li, 2011. Powers of Exclusion: Land Dilemmas in Southeast Asia. Singapore: NUS Press.

Herzfeld, M., 2016. Siege of the Spirits: Community and Polity in Bangkok. Chicago: University of Chicago Press. doi.org/10.7208/ chicago/9780226331751.001.0001. 
Hirsch, P., 2011. 'Titling against Grabbing? Critiques and Conundrums around Land Formalisation in Southeast Asia.' Paper presented at the International Conference on Global Land Grabbing, Institute of Development Studies, University of Sussex, 6-8 April.

Hirsch, P. and N. Scurrah, 2015. 'The Political Economy of Land Governance in the Mekong Region.' Vientiane: Mekong Region Land Governance.

Hughes, H., 2004. 'Can Papua New Guinea Come Back from the Brink?' Sydney: The Centre for Independent Studies (Issue Analysis 49).

Kristiansen, S. and L. Sulistiawati, 2016. 'Traditions, Land Rights, and Local Welfare Creation: Studies from Eastern Indonesia.' Bulletin of Indonesian Economic Studies 52(2): 1-29. doi.org/10.1080/000749 18.2015.1129049.

Laovakul, D., 2015. 'Concentration of Land and Other Wealth in Thailand.' In P. Phongpaichit and C. Baker (eds), Unequal Thailand: Aspects of Income, Wealth and Power. Singapore: NUS Press.

Milne, S., 2013. 'Under the Leopard's Skin: Land Commodification and the Dilemmas of Indigenous Communal Title in Upland Cambodia.' Asia Pacific Viewpoint 54(3): 323-339. doi.org/10.1111/apv.12027.

Peluso, N.L., 1995. 'Fruit Trees and Family Trees in an Anthropogenic Forest: Ethics of Access, Property Zones, and Environmental Change in Indonesia.' Comparative Studies in Society and History 38(3): 510-548. doi.org/10.1017/S0010417500020041.

Rose, C.M., 1994. Property and Persuasion: Essays on the History, Theory, and Rhetoric of Ownership. Boulder (CO): Westview Press.

Scott, J.C., 1976. The Moral Economy of the Peasant: Rebellion and Subsistence in Southeast Asia. New Haven (CT): Yale University Press.

—_, 1985. Weapons of the Weak: Everyday Forms of Peasant Resistance. New Haven (CT): Yale University Press.

Springer, S., 2009. 'Renewed Authoritarianism in Southeast Asia: Undermining Democracy through Neoliberal Reform.' Asia Pacific Viewpoint 50(3): 271-276. doi.org/10.1111/j.14678373.2009.01400.x. 
This text is taken from Kastom, property and ideology: Land transformations in Melanesia, edited by Siobhan McDonnell, Matthew Allen and Colin Filer, published 2017 by ANU Press, The Australian National University, Canberra, Australia. 